Article

\title{
Australian Construction and Demolition Waste Management System in Australia: Investigation of Challenges and Opportunities
}

\author{
Salman Shooshtarian *, Tayyab Maqsood, Peter S.P. Wong, Malik Khalfan, and Rebecca J. Yang \\ School of Property, Construction and Project Management, RMIT University, Melbourne, Australia; \\ Tayyab.maqsood@rmit.edu.au (T.M.); Peterspwong@rmit.edu.au (P.S.P.W.); Malik.khalfan@rmit.edu.au \\ (M.K.); Rebecca.yang@rmit.edu.au (R.Y.) \\ * Correspondence: salman.shooshtarian@rmit.edu.au
}

Received: 9 June 2020; Accepted: date; Published: date

\begin{abstract}
Increased construction activities in Australia have led to the generation of a massive volume of construction and demolition (C\&D) waste annually. Management of this volume of waste requires an effective waste framework. The literature reported that the current Australian waste framework does not meet expectations and needs immediate improvements. This study was therefore conducted to seek the key C\&D stakeholders' opinion about various issues identified in this waste stream. The specific objectives of this study are identification of the main barriers to effective $C \& D$ waste management, the impact of current regulations and opportunities to enhance the current C\&D waste management system. A survey was conducted in 2019 to capture the stakeholders' perception. 132 participants from various industries and government agencies based in various Australian jurisdictions took part in the survey. The key results showed that the main barriers towards an effective management system are "overregulation, tough acceptance criteria, and increased testing requirements", "lack of local market" and "culture, poor education and low acceptance". Furthermore, a low number of participants indicated that the current legislation encourages waste recovery activities. The main areas of improvements included "providing a guideline that determines the accepted level of contamination for reusing C\&D waste", "preparation of guidelines on requirements of using recycled C\&D materials in different industries" and "setting target for reduction, reusing, and recycling C\&D waste". The results can inform policy development and be used as evidence for a broader discussion to solve lasting issues in C\&D waste management.
\end{abstract}

Keywords: Sustainable procurement, Waste policy, C\&D waste regulation, Overregulation, Recycled waste materials

\section{Introduction}

Australia's capital cities have experienced unprecedented construction activities to meet the needs of the growing population and keep up with economic growth [1]. As a result, the management of the ensuing construction and demolition (C\&D) waste has become an emerging issue, notably in urban areas [2]. The construction industry is responsible for $43 \%$ of the solid waste generated every year in Australia [3]. Australia is among the top 10 countries in the Organisation for Economic Cooperation and Development (OECD) for 
levels of solid waste generated. In 2017-18, a total of 20.4 million tonnes of C\&D waste were generated in Australia [3].

It is reported that the waste management system has not succeeded in the effective management of the C\&D waste stream [2]. A part of this issue is attributed to waste regulation [4-7]. Notably, it is argued that waste regulations are not as effective as they should be. C\&D waste is regulated differently in Australia's jurisdictions and territories [8], and thus, a new holistic national approach is required. In the Australian context, the federal government is not directly involved in regulating $C \& D$ waste unless the regulations set by state governments are in conflict with international treaties to which Australia is a party (e.g. Agenda 21, Basel Conventions and Stockholm Conventions) or they impose threats to the environment that are of national concern. Technically, local governments and municipalities provide waste collection and recycling services, manage and operate or administrate landfill sites, deliver education and awareness programs, and provide and maintain recycling infrastructure [9]. Therefore, the majority of legislation occurs at state and territorial government level. C\&D waste management in each state/territory builds on the specific regulatory framework that prevails in that state. A particular issue with this regulatory approach is the emergence of inconsistencies between jurisdictional regulations. These inconsistencies give rise to barriers that impede effective $C \& D$ waste management activities $[7,10,11]$. In the previous literature, several of these barriers were already identified $[2,7$, 10, 12-14] and relevant recommendations have already been made.

Given the waste management status quo, more calls have now been made by the industry and general public urging the federal government to interfere and play a more decisive role. There are many ways that the federal government can be influential in this space, including but not limited to, policy development, provision of incentives, investment and supporting waste recovery activities [15].

Policy development in the context of C\&D waste is believed to be a stepping stone for harmonized waste avoidance and increased resource recovery activities across Australia. Waste strategy documents issued in different states and territories have emphasised the 
contribution to waste policy and programs aimed at waste avoidance, resource recovery and environmental protection [16]. In Australia, the first national waste policy was developed in 2009, which was then updated in 2018. The latter was prepared by the Australian Government, state and territory governments and the Australian Local Government Association [9]. The National Waste Policy 2018 provides a national framework for waste and resource recovery in Australia. It outlines roles and responsibilities for collective action by businesses, governments, communities and individuals.

Furthermore, there are multiple advisory and mandatory schemes that can help with reducing the volume of $C \& D$ waste going into landfills. These include 'manufacturer's shared responsibility', 'imposition of tax on virgin materials', 'providing subsidy for recycled C\&D waste-derived products', 'Green Star (GS) rating tool', 'Sustainable Infrastructure (SI) rating tool', 'emission trading scheme', and 'proximity principles'. Extended Producer Responsibility (EPR) is found to be a successful market-based policy approach that has been applied to different waste types and streams [17]. Technically, EPR makes manufacturers responsible (financially and/or physically) for the entire lifecycle of their products during the supply chain of materials, including design, manufacture, recycling and final disposal [18]. EPR provides an opportunity to divert additional waste away from landfills to reuse and recovery. EPR has been recognised as an incentive for producers to take into account environmental considerations when designing their products, resulting in preventing waste at the source through better product design [11].

Despite it being technically achievable to recycle most construction materials, the type and amount of material to be salvaged is often highly dependent on its value [19]. The value of C\&D waste-derived materials in most circumstance is a function of the price of new extracted or imported materials. To change the game in favour of C\&D recycled materials, a relatively new financial incentive has emerged that is intended to discourage consumers from using raw materials in their construction projects. This incentive can be applied in two forms: 'taxing on the use of virgin materials' or 'removing subsidies for virgin materials'. These two price mechanisms have proven to increase the competitiveness of salvaged and recycled C\&D materials in several countries. For instance, since 2002, a regulation [20] has 
been imposed in the UK to make recycled C\&D waste more competitive relative to the virgin aggregates. The levy is a tax ( $£ 2$ per tonne) on the commercial exploitation of rock, sand and gravel, and it aims to adjust the price of virgin aggregates to reflect their intrinsic environmental costs better. The tax is further expanded to target imported materials. A similar tax has also been implemented in some EU countries, including France, Denmark and Sweden [21].

Levy revenue could be used to invest in the development of a market for recycled materials through low-interest (subsidised business) loans or financial incentives and R \& D [11, 15]. Green construction has proven to play a critical role in boosting C\&D waste market worldwide, mainly when it is implemented obligatorily and is a requirement for large scale or government projects. In Australia, there are two voluntary industry-based rating systems, namely the 'Green Star program' and 'green infrastructure', which promote the concept of green construction [22].

The issue of carbon emission with regards to $C \& D$ waste management is complex. On the one hand, carbon emissions during recycling are inevitable; however, measures for the substantial reduction in emissions are possible and very crucial to protect the environment. On the other hand, the options of landfill disposal and extraction of virgin materials have far more adverse environmental consequences [23]. In emission trading, the main authority allocates a limited number of permits to dispose of a certain amount of a specific pollutant during the time period stipulated [24]. Polluters (waste producers) need to own permits in an amount equal to their emissions. Polluters that wish to add to their emissions should purchase permits from others willing to sell them. ETS in Australia has been a point of disagreement between the major political parties because of its social and economic effects. Between 2003 and 2011, policies related to ETS were passed and overturned several times. The Parliament of Australia has provided a list of pros and cons of ETS in relation to varying factors [11]. Proximity principle (PP) is another scheme that requires waste generators to send their waste to a facility that is located in a certain perimeter of origin. Several submissions to the Environment and Communications References Committee (2018) argued that the PP could assist in preventing movement of waste between jurisdictions to avoid or minimise levy liabilities [11]. 
There is a hanful of research in the context of Australia [1-4] that provides information on how $C \& D$ waste key stakeholders perceive the issues and opportunities relating to $C \& D$ waste management practices. Therefore, this study aims to understand key stakeholders' perceptions with a focus on three areas as follows:

1. Understanding of the main barriers to the effective management of C\&D waste

2. The role of federal government in C\&D waste management

3. Exploring the perceptions around waste regulations, policies and schemes

The study is part of a larger national study (Project 1.65. A National Economic Approach to Improved Management of Construction and Demolition Waste) that investigated the harmonisation of C\&D waste management systems in Australia. The study was funded by the Australian Sustainable Built Environment National Research Centre (2018-2020).

\section{Methodology}

\subsection{Sample and data collection}

A survey was conducted in 2019 to capture the C\&D waste management stakeholders' perceptions. Recruitment was executed according to the Australian National Statement on Ethical Conduct in Human Research and RMIT University Human Ethics Committee instructions and requirements. The project industry partners including the Waste Management and Resource Recovery Association of Australia (WMRRA) and the Australia Sustainable Built Environment National Research Centre (SBErnc) assisted with recruitment process through providing their network contact details. Email communication was the method of recruitment. An email, including the online link to the survey and the information sheet, was sent to 250 individuals inviting them to participate. A reminder email was also sent to those who did not respond to the survey in the first round. Participation in this study was voluntary and a completed survey implied informed consent. The investigators maintained the privacy and confidentiality of all information collected in the study as per given human ethics requirements. 


\subsection{Questionnaire}

A questionnaire was developed to investigate how various issues and opportunities in the $C \& D$ waste stream are perceived among participants. The questionnaire was created in an online environment using the Qualtrics toolkit [25]. The completed survey was reviewed by experts to establish content validity and then tested for online accessibility and comprehension by a group of construction professionals and researchers. The content, clarity and length of the survey were then modified accordingly. The questionnaire consisted of several questions covering the main issues and opportunities in the Australian C\&D waste management system [15]. The survey design consisted of multiple-choice questions (e.g. 'true'/'false'/'not sure'), 5- and 7-point Likert scales (1 = 'strongly agree' to 7 = 'strongly disagree'), single and multiple text entry(ies), and rank ordering (1 to 5). Furthermore, a series of questions were presented to the participants seeking their opinions about the validity of the survey. The average response time was recorded to be between 25 and 30 minutes. This paper only presents the four areas of the questionnaire that addressed (1) participants' characteristics, (2) barriers to the effective management of C\&D waste, (3) the Australian federal government position in waste management and (4) waste related regulations, policies and schemes. The questions included in each of these domains are presented in the results section.

\subsection{Data analysis and presentation}

In total, 132 responses were received and recorded in the Qualtrics database. After screening the responses, the data from the survey was analysed using Excel Spreadsheets version 2016. To explore the participants' demographic details and their opinion on the C\&D waste issues and opportunities, descriptive statistical analyses were used. Frequency distribution was the main statistical measure to compare different categories of responses received from participants. Excel Spreadsheets v. 2016 was also used to present the results in the form of graphs and tables. 


\section{Results}

\subsection{Participants' profile}

The profile of the participants, including the industry and geographical zone in which they performed their main activities and the length of their experience, were explored. More than $50 \%$ of the participants belonged to three sectors: waste recovery $(20 \%)$, construction $(16 \%)$ and landfilling (15\%). As shown in Table 1, about $44 \%$ of participants had less than six years of experience working in the C\&D waste space and less than $30 \%$ of them had worked in an industry related to $C \& D$ waste management for more than 15 years at the time of survey completion. More than $60 \%$ of participants were based in two large states, Vic and NSW (Table 1).

Table 1. Study participants' profile.

\begin{tabular}{|c|c|c|c|c|c|c|c|c|c|c|}
\hline \multicolumn{11}{|c|}{ Field of activity } \\
\hline 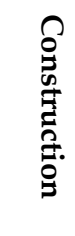 & 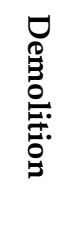 & 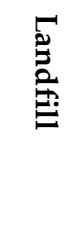 & 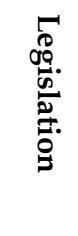 & 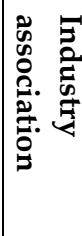 & 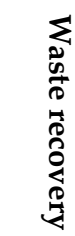 & 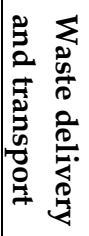 & 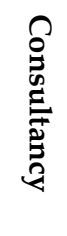 & 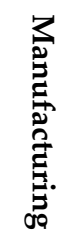 & $\underset{\varnothing}{\approx}$ & 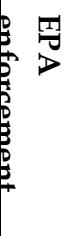 \\
\hline 16 & 8 & 15 & 6 & 6 & 20 & 10 & 7 & 4 & 3 & 5 \\
\hline \multicolumn{11}{|c|}{ Experience } \\
\hline \multicolumn{3}{|c|}{$>6$ years } & \multicolumn{3}{|c|}{ 6-10 years } & \multicolumn{3}{|c|}{ 11-15 years } & \multicolumn{2}{|c|}{$>15$ years } \\
\hline \multicolumn{3}{|c|}{43.1} & \multicolumn{3}{|c|}{13.7} & \multicolumn{3}{|c|}{16.7} & \multicolumn{2}{|c|}{26.5} \\
\hline \multicolumn{11}{|c|}{ State/territory } \\
\hline \multicolumn{2}{|c|}{ ACT } & \multicolumn{2}{|c|}{ NSW } & NT & Qld & Tas & \multicolumn{2}{|l|}{ Vic } & \multicolumn{2}{|l|}{ WA } \\
\hline \multicolumn{2}{|l|}{1.8} & \multicolumn{2}{|c|}{24.3} & 6.3 & 16.2 & 3.6 & \multicolumn{2}{|c|}{30.6} & \multicolumn{2}{|l|}{17.1} \\
\hline
\end{tabular}

\subsection{Barriers to effective $C \& D$ waste management}

Participants were asked to list multiple factors that they perceived to be the main barriers to effective $C \& D$ waste management. Responses from participants suggested that there is a wide array of barriers that can negatively impact the Australian waste management system. To further analyse these factors, they were categorised into 19 major groups. Figure 1 displays the frequency distribution of these major groups of barriers identified by the 
participants. The analytical results showed that the most frequently referenced factors included "overregulation, recycled materials acceptance criteria set by government agencies and increased testing" (13.4\%), "lack of local market" (9.8\%) and "culture, poor education (attitude and behaviour) and acceptance" (8.5\%)". 


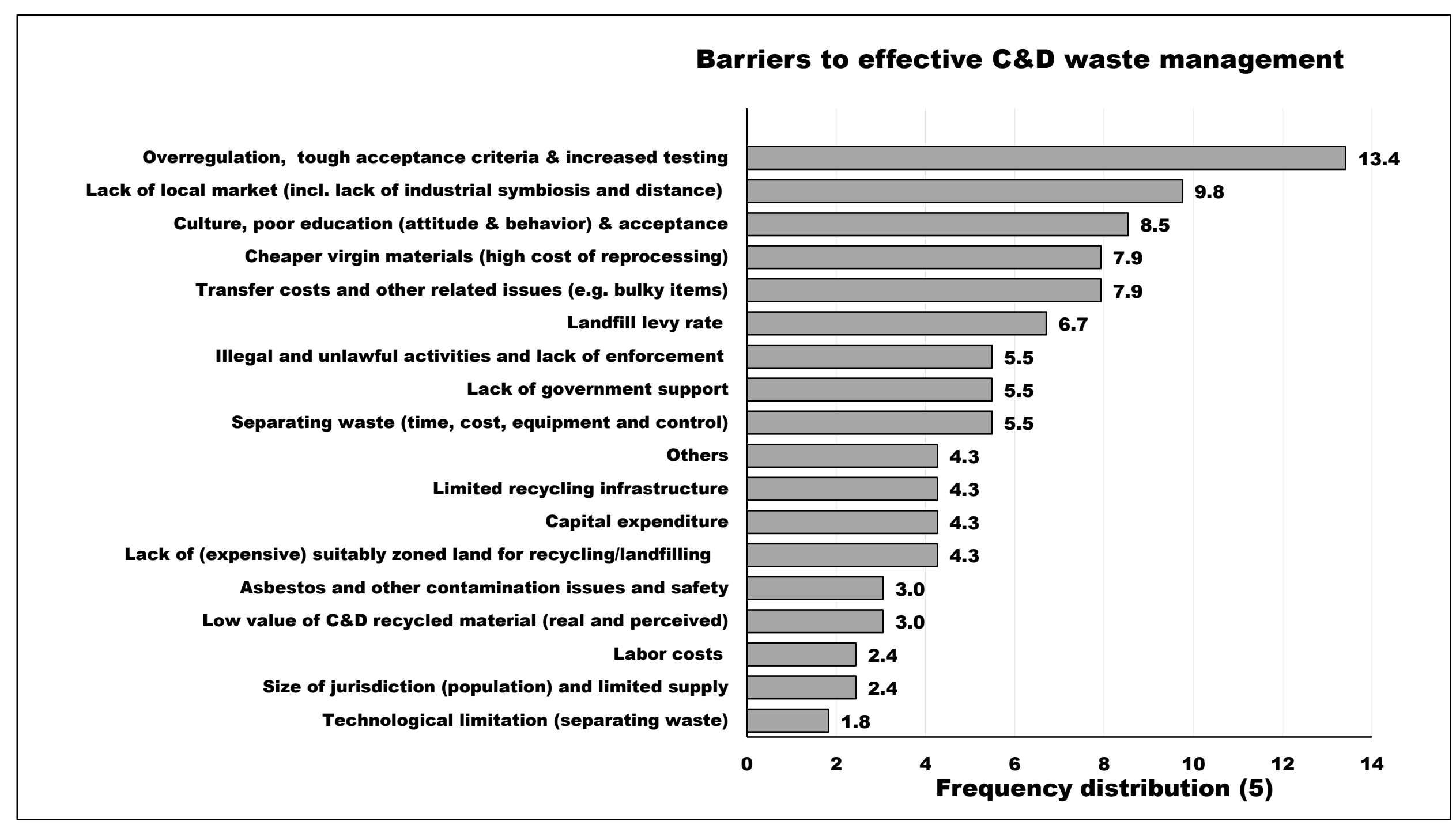

Figure 1. Main barriers to effective C\&D waste management in Australia

\section{Barriers to effective C\&D waste management} ack of local market (incl. lack of industrial symbiosis and distance) Culture, poor education (attitude $\&$ behavior) $\&$ acceptance Cheaper virgin materials (high cost of reprocessing) Landfill levy rate

Separating waste (time, cost, equipment and control)

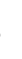

Figure 1. Main barriers to effective C\&D waste management in Australia

ransfer costs and other related issues (e.g. bulky items)

Illegal and unlawful activities and lack of enforcement Capital expenditure

ues and safety Size of jurisdiction (population) and limited supply Technological limitation (separating waste)

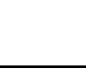

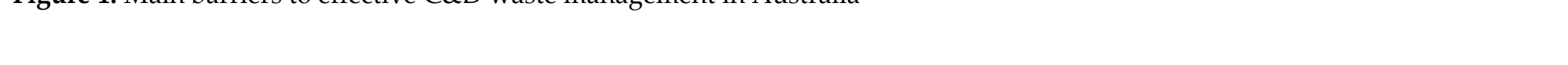




\subsection{Government}

The federal government plays a critical role in the planning and implementation of an integrated waste management system. Despite the statutory jurisdictional duty of the Australian jurisdiction, the federal government has powerful tools to coordinate the disjointed efforts across states and territories. With this assumption in mind, the participants were asked to express their level of agreement about some of the potentials roles that the federal government may take to improve waste management. The proposed contributions were extracted from the desktop research and C\&D waste experts' opinions. These included "legislation", "investment in technology and waste facility", "providing national leadership and coordination of C\&D waste efforts", "mandating waste data reporting", "building confidence in C\&D salvaged and recycled materials in the market", "providing practical support for sustainable procurement", "extended producer responsibility" and "GST subsidy for C\&D recycled materials". The analytical results showed that-except for "providing GST subsidy for recycled materials", which had more disagreement votes against-survey participants substantially agreed that the other roles could contribute to the effective management of C\&D waste (Figure 2). The most supported potential impacts of the federal government were identified to be "building confidence in C\&D salvaged and recycled materials in the market" (97.5\%) "providing national leadership and coordination of C\&D waste efforts" (93.8\%) and "legislation" (93.7\%). 


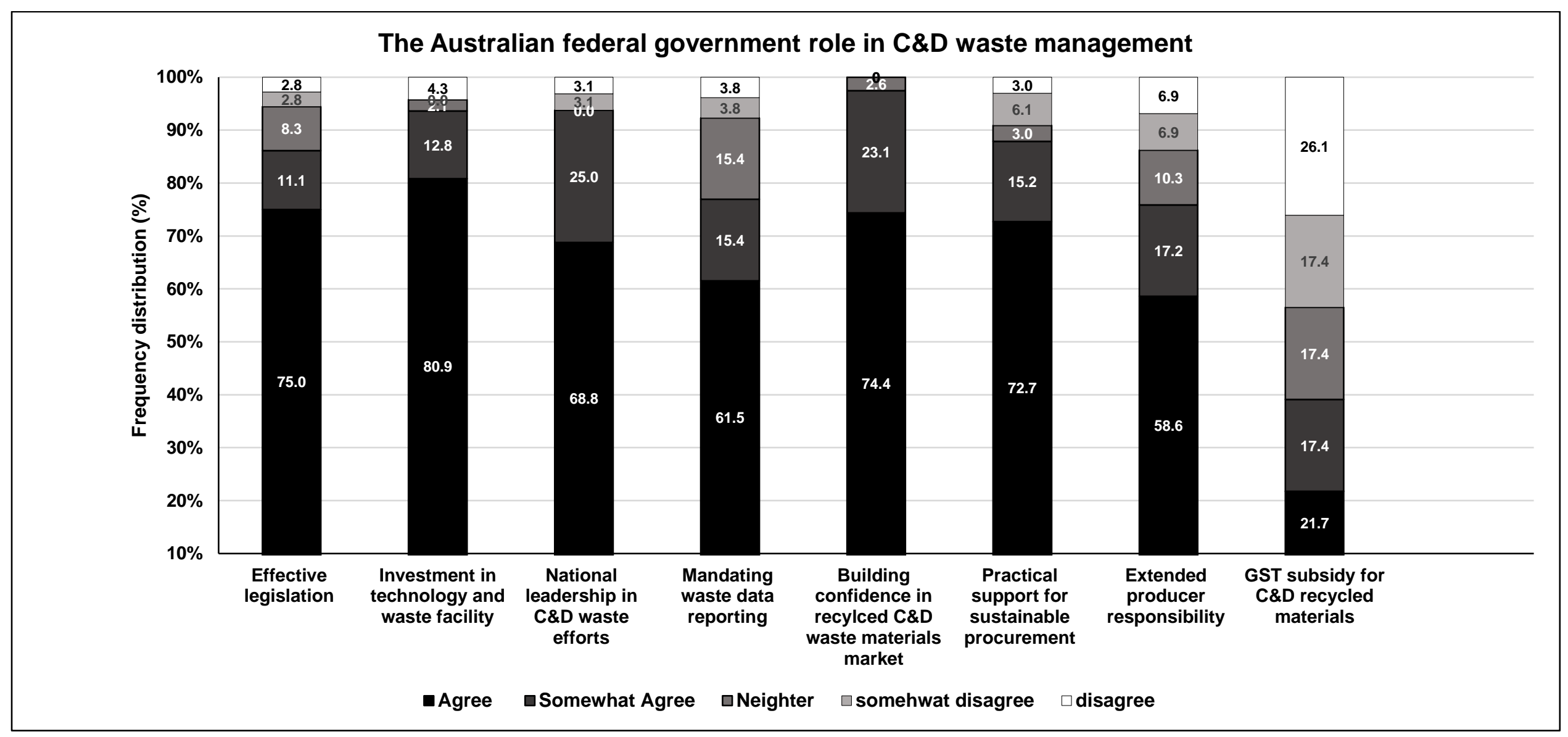

Figure 2. The role of the Australian federal government in the C\&D waste management framework 


\subsection{C\&D waste regulations: Issues}

Legislation has a substantial impact on the way that $C \& D$ waste is managed. Among the various reasons why legislation is of particular importance is the lack of consensus about the adequacy of current regulations in Australian jurisdictions. Participants were asked to indicate if the current legislation supports or discourages $C \& D$ waste reduction, reuse and recycling in their jurisdiction. The resultant frequency distribution showed that more than $45 \%$ of participants think that the current regulations are not in favour of more recycling and waste minimisation activities (Figure 3).

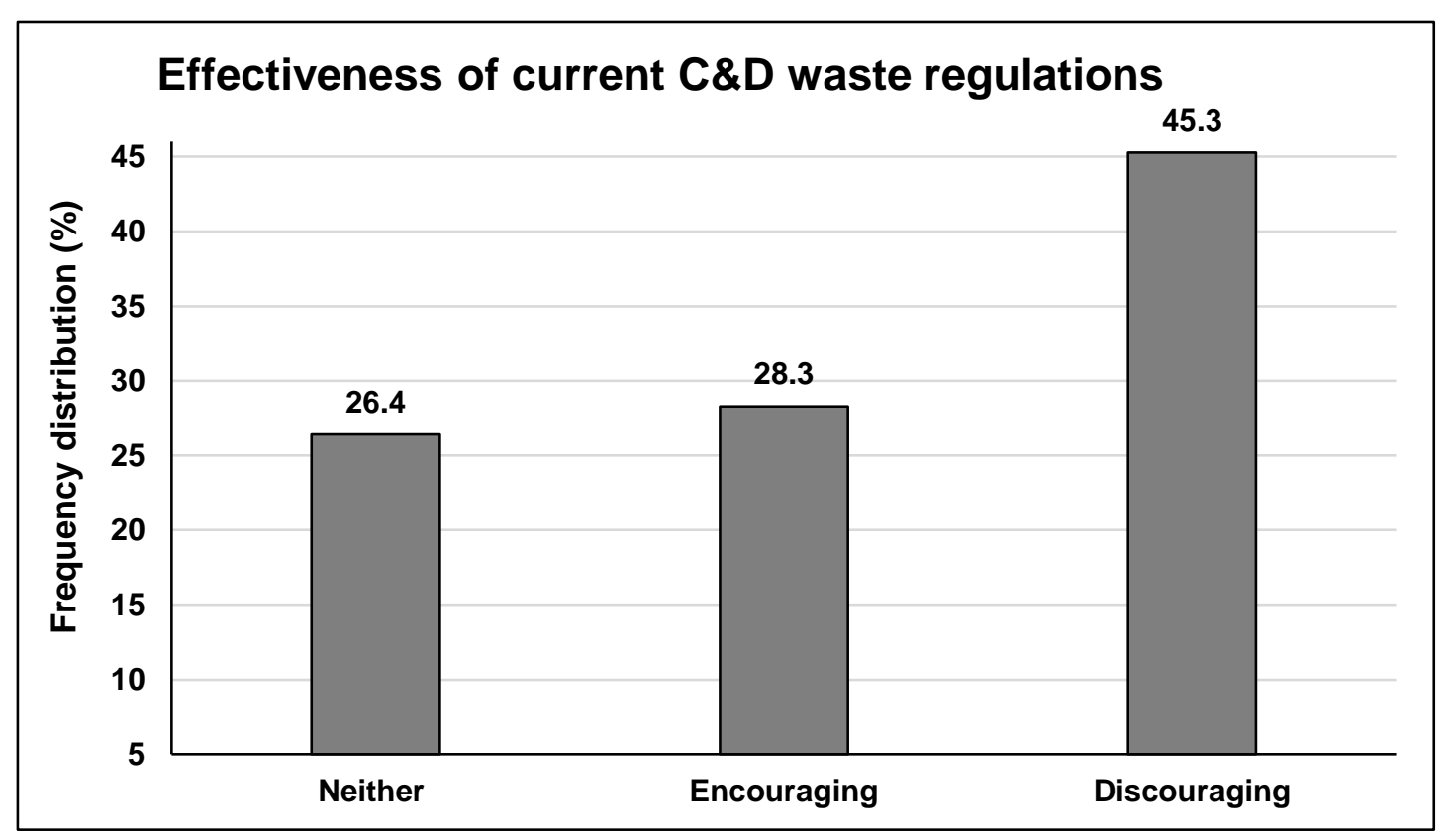

Figure 3. The effectiveness of the current $C \& D$ waste regulations in discouraging further waste recovery

To obtain more uniform categories to describe the issues with the current regulations, and to make sure that participants were aware of the issues that had been identified from desktop research at the time of the survey, they were provided with a range of options from which to choose. As depicted in Figure 4, the three main issues were found to be "illegal dumping and stockpiling" (18.9\%), "definition and classification of C\&D waste" (16.5\%) and “extended producer responsibility" (13.4\%). 


\section{Three main issues in current regulations}

Illegal dumping and stockpilling

Definition and classification of C\&D waste

Extended producer responsbility

Waste data management and reporting

Development of waste strategy

Distribution of levy revenue

Levy imposition

Licencing

Law enforcement requirements

Others

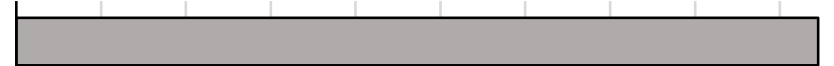

18.9

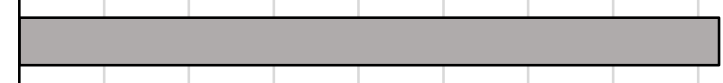

16.5

13.4

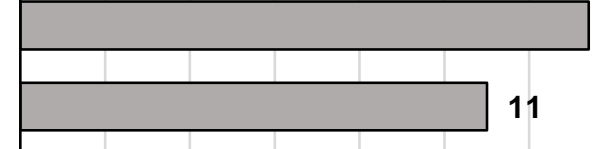

9.4
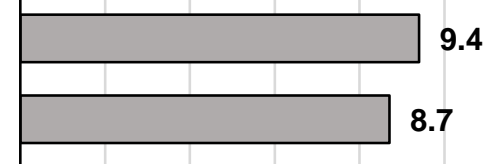

7.9

6.3

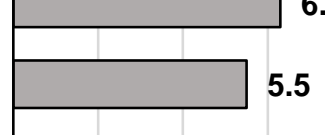

5.5

1.6

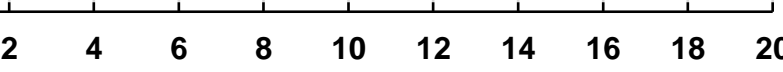

Frequency distribution (\%)

Figure 4. The main three issues in current legislations

To further understand how the current legislation operates in favour of or against successful planning and implementation of effective waste management, participants were later required to provide a reason for their choice. Their qualitative responses were diverse and hence could not be usefully categorised. These issues were reported based on the inconsistencies perceived by respondents from C\&D waste regulation. Table 2 provides the participants' qualitative responses. The main two categories include an inconsistent levy system and complex recycled waste criteria between jurisdictions.

Table 2. Participants' responses to the inconsistencies in the current C\&D waste regulations
No Description
No Description

Inconsistency 1 


\begin{tabular}{|c|c|c|c|}
\hline 1 & Where does it go? & 19 & $\begin{array}{l}\text { Lack of recycling options in procurement } \\
\text { policies }\end{array}$ \\
\hline 2 & Waste transport certificate & 20 & lack of processing facilities for C\&D products \\
\hline 3 & $\begin{array}{l}\text { Waste levy costs appear inconsistent and this } \\
\text { appears to drive the wrong behaviour ie. we } \\
\text { truck waste to another jurisdiction where levy } \\
\text { costs are lower. }\end{array}$ & 21 & $\begin{array}{l}\text { lack of compliance of regulations in WA } \\
\text { especially on illegal operations }\end{array}$ \\
\hline 4 & $\begin{array}{l}\text { WA requires much higher product testing of } \\
\text { composition than other states }\end{array}$ & 22 & $\begin{array}{l}\text { In WA we have overwritten specifications that } \\
\text { we cant match in manufacture }\end{array}$ \\
\hline 5 & Variable levies between states & 23 & $\begin{array}{l}\text { In NSW a recycled waste product is still defined } \\
\text { as a waste even when it meets an Australian } \\
\text { Standard equivalent to a natural product. In } \\
\text { Victoria, it is no longer a waste once its recycled } \\
\text { into an approved product. }\end{array}$ \\
\hline 6 & Uniform levies & 24 & every state has different rules \\
\hline 7 & $\begin{array}{l}\text { tracking paperwork - more admin can stop } \\
\text { people completing the task }\end{array}$ & 25 & driving recycling when there is no market \\
\hline 8 & $\begin{array}{l}\text { Standards - there should be a consistent set of } \\
\text { national standards for recycled C\&D products } \\
\text { and end-uses to provide confidence to the } \\
\text { market }\end{array}$ & 26 & $\begin{array}{l}\text { different taxation policy regarding the C\&D } \\
\text { waste stream }\end{array}$ \\
\hline 9 & Poor market development & 27 & Different requirements in different states \\
\hline 10 & $\begin{array}{l}\text { Planning and approval process to licence new } \\
\text { resource recovery facilities }\end{array}$ & 28 & Different regs across states \\
\hline 11 & $\begin{array}{l}\text { NT- lack of government requirements to reuse } \\
\text { recycled C\&D waste in all projects }\end{array}$ & 29 & $\begin{array}{l}\text { Definitions of what is classified as a "waste" and } \\
\text { what is a "material" for reuse. }\end{array}$ \\
\hline 12 & Not familiar with other legislation outside WA & 30 & Data collection \\
\hline 13 & $\begin{array}{l}\text { No responsibility of producers - Housing } \\
\text { department creates the waste, but takes no } \\
\text { responsibility (Councils are faced with } \\
\text { overflowing landfills and no equipment to } \\
\text { handle the C\&D waste) }\end{array}$ & 31 & Cross state border differences in regulation \\
\hline 14 & no requirement to be a mandatory activity & 32 & Cheaper to landfill \\
\hline 15 & no procurement incentive & 33 & Cheaper to import virgin materials \\
\hline 16 & metro levy vs no regional levy & 34 & $\begin{array}{l}\text { Business waste stream costs set to a national } \\
\text { standard }\end{array}$ \\
\hline 17 & lower barriers for use of recycled materials. & 35 & $\begin{array}{l}\text { Allowable asbestos limits in Victoria and WA } \\
\text { however no allowable limit in NSW }\end{array}$ \\
\hline 18 & levy variations & 36 & Aggregates reuse specification \\
\hline \multicolumn{4}{|c|}{ Inconsistency 2} \\
\hline 1 & Waste Classifications - set national standards & 16 & $\begin{array}{l}\text { Manufacturers have minimal incentive or buy } \\
\text { in }\end{array}$ \\
\hline 2 & Varying levy rates between states & 17 & $\begin{array}{l}\text { Lack of use of recycled products by government } \\
\text { and construction sector }\end{array}$ \\
\hline 3 & $\begin{array}{l}\text { various levy rates across the Australian } \\
\text { jurisdictions }\end{array}$ & 18 & $\begin{array}{l}\text { increase landfill levies to assist in sending C\&D } \\
\text { waste to recyclers, }\end{array}$ \\
\hline 4 & $\begin{array}{l}\text { Transportation costs for some local councils } \\
\text { away from the CBD }\end{array}$ & 19 & Inconsistent reporting requirements \\
\hline
\end{tabular}




\begin{tabular}{|c|c|c|c|}
\hline 5 & $\begin{array}{l}\text { The regulations, licensing costs and } \\
\text { application processes for reprocesses are too } \\
\text { onerous }\end{array}$ & 20 & $\begin{array}{l}\text { In SA they have the sustainable aggregates } \\
\text { association for testing costs reduction and } \\
\text { brand development of C\&D materials. }\end{array}$ \\
\hline 6 & $\begin{array}{l}\text { testing - why does recycled content have to be } \\
\text { tested so much \& virgin not when the same } \\
\text { risks are involved especially for companies } \\
\text { that blend virgin product with recycled \& } \\
\text { don't have to test. }\end{array}$ & 21 & Expensive to process recycled materials \\
\hline 7 & SV should have more guides & 22 & $\begin{array}{l}\text { DWER imposes a restriction on locations and } \\
\text { uses }\end{array}$ \\
\hline 8 & products in some states are no excepted & 23 & $\begin{array}{l}\text { driving recycling when there is no } \\
\text { infrastructure }\end{array}$ \\
\hline 9 & $\begin{array}{l}\text { Procurement - recyclables are generally not } \\
\text { allowed in construction projects (not included } \\
\text { in Tenders) }\end{array}$ & 24 & $\begin{array}{l}\text { Does not flow from National to State to Local } \\
\text { government }\end{array}$ \\
\hline 10 & Pricing of the levy varies across the country & 25 & Cross-state border differences in landfill levies \\
\hline 11 & Poor procurement policy settings & 26 & Cowboy transport company \\
\hline 12 & $\begin{array}{l}\text { Overzealous testing requirements in WA for } \\
\text { product acceptance }\end{array}$ & 27 & Consistent licence conditions \\
\hline 13 & $\begin{array}{l}\text { NT- lack of any regulatory incentives not to } \\
\text { just dispose of, }\end{array}$ & 28 & $\begin{array}{l}\text { Asbestos has a very low allowable limit in most } \\
\text { states except NSW. In NSW one fibre of asbestos } \\
\text { in a stockpile of crushed concrete makes it a } \\
\text { stockpile of asbestos waste. }\end{array}$ \\
\hline 14 & no proximity rules & 29 & $\begin{array}{l}\text { acceptable contaminant levels in recovered } \\
\text { C\&D materials }\end{array}$ \\
\hline 15 & no awareness campaigns & & \\
\hline \multicolumn{4}{|c|}{ Inconsistency 3} \\
\hline 1 & Waste removal fees vary significantly & 12 & $\begin{array}{l}\text { In NSW waste is always defined as a waste even } \\
\text { after its recycled. In Victoria its no longer a } \\
\text { waste if it meets a suitable standard or } \\
\text { specification. }\end{array}$ \\
\hline 2 & $\begin{array}{l}\text { Vic is the only state that mandates } 20 \% \\
\text { recycled aggregates must be used - all other } \\
\text { states should comply }\end{array}$ & 13 & $\begin{array}{l}\text { In NSW its very difficult to use C\&D wood } \\
\text { waste as a fuel. In other states its widely used as } \\
\text { a fuel. }\end{array}$ \\
\hline 3 & $\begin{array}{l}\text { Some municipalities are cheaper to operate } \\
\text { reprocessing in than others }\end{array}$ & 14 & governments not leading by example \\
\hline 4 & $\begin{array}{l}\text { Requirements for recycling facilities vary } \\
\text { between states }\end{array}$ & 15 & $\begin{array}{l}\text { Government procurement does not mandate to } \\
\text { purchase recycled content products }\end{array}$ \\
\hline 5 & $\begin{array}{l}\text { NT- lack of consistency and recognition of the } \\
\text { issues in relevant NTG Planning, NTG } \\
\text { development and NT EPA, }\end{array}$ & 16 & different recycling targets \\
\hline 6 & no financial incentives for best practice & 17 & Definitions inconsistencies \\
\hline 7 & $\begin{array}{l}\text { Licensing conditions applicable vary - when } \\
\text { the waste type/risks are the same. }\end{array}$ & 18 & $\begin{array}{l}\text { Cross state border differences in return of } \\
\text { landfill levy revenue }\end{array}$ \\
\hline 8 & legislation differences between states & 19 & costs associated with sorting the C\&D waste \\
\hline 9 & $\begin{array}{l}\text { Lack of strong guidance from EPA on use of } \\
\text { recycled materials }\end{array}$ & 20 & $\begin{array}{l}\text { Consistent planning approvals and } \\
\text { enforcement. }\end{array}$ \\
\hline 10 & Inconsistent licencing requirements & 21 & Any landfill can take it \\
\hline
\end{tabular}


\begin{tabular}{l|l|l|l|l}
11 & In QLD the levy is so low that it takes mixed & 22 & acceptance and product requirements
\end{tabular} C\&D waste from potential markets in NSW.

\subsection{Policy development}

Non-legislative policies and guidelines are an important source of information and guidance for the stakeholders of waste management in Australia. Hence, participants were asked to indicate the five main areas of improvement that can be facilitated through policy development. The proposed improvement areas include:

(1) Preparation of guidelines on siting, design, operation, and rehabilitation of landfills that can best match the waste hierarchy objectives

(2) Preparation of guidelines on requirements of using recycled C\&D materials in different industries

(3) Sustainable procurement guidelines

(4) Policies on how to share the responsibility of waste with its producers

(5) Setting target for reduction, reusing, and recycling C\&D waste

(6) Providing a guideline that determines the accepted level of contamination for reusing C\&D waste

(7) Development of a state-wide waste and resource recovery infrastructure plan

(8) Providing guidelines on Energy-from-Waste (energy recovery)

(9) Provide regulatory support for both fixed and mobile crushing and screening equipment

(10) Development of policies to manage emergency C\&D waste in natural disaster incidents (i.e. earthquake, landslide, or flood)

(11) Provide a clear process for determining license requirements or exemptions based on environmental risk

(12) Development of evidenced (research) based strategies to manage C\&D waste

(13) Others (please specify)

The results of their responses are provided in Figure 5. The five main areas were found to be "Providing a guideline that determines the accepted level of contamination for reusing C\&D waste" (61.4\%), "Preparation of guidelines on requirements of using recycled C\&D materials in different industries" (59\%), "Setting target for reduction, reusing and recycling C\&D waste" (54.5\%) "sustainable procurement guideline" (43.2\%) and “Development of a statewide waste resource recovery infrastructure plan" (43.2\%). 


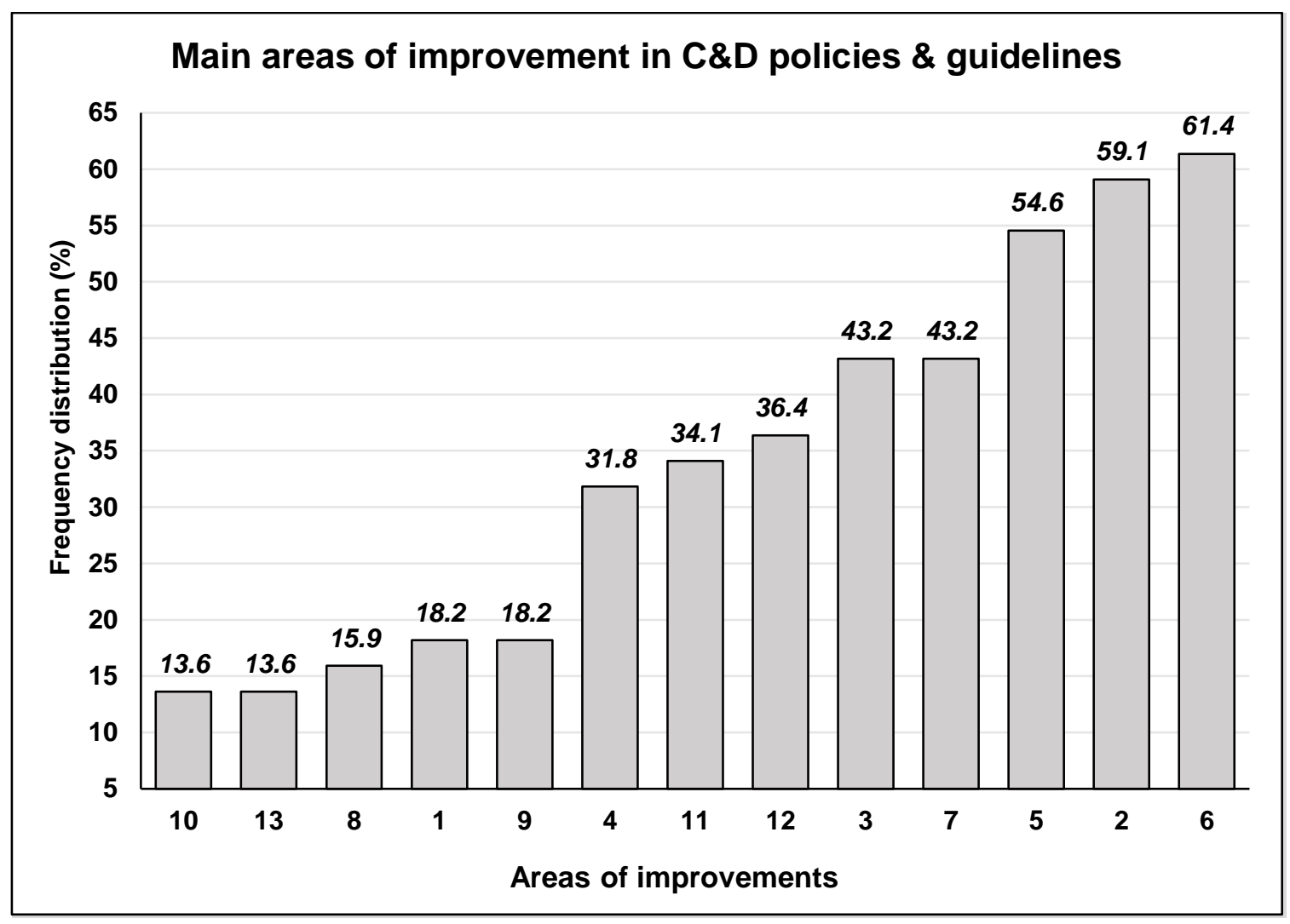

Figure 5. Five areas of improvement in non-legislative C\&D waste policies and guidelines

\subsection{Waste management schemes}

Six waste management schemes (advisory/mandatory) that had been identified in the desktop research were presented to participants to understand their position about their effectiveness. These schemes include "manufacturer's shared responsibility", "imposition of tax on virgin materials", "providing subsidy for recycled C\&D waste-derived products", "Green Star rating tool", "Sustainable Infrastructure rating tool", "emission trading scheme" and "proximity principle". As presented in Figure 6, "manufacturer's shared responsibility of waste generation" (86.4\%), "subsidy for C\&D waste recycled materials" (81.4\%) and "proximity principle" (78.6\%) received the highest rate of a level of agreement by the respondents. In the case of manufacture's shared responsibility, several responses highlighted that the scheme encourages producers to design and produce a readily recyclable material. 


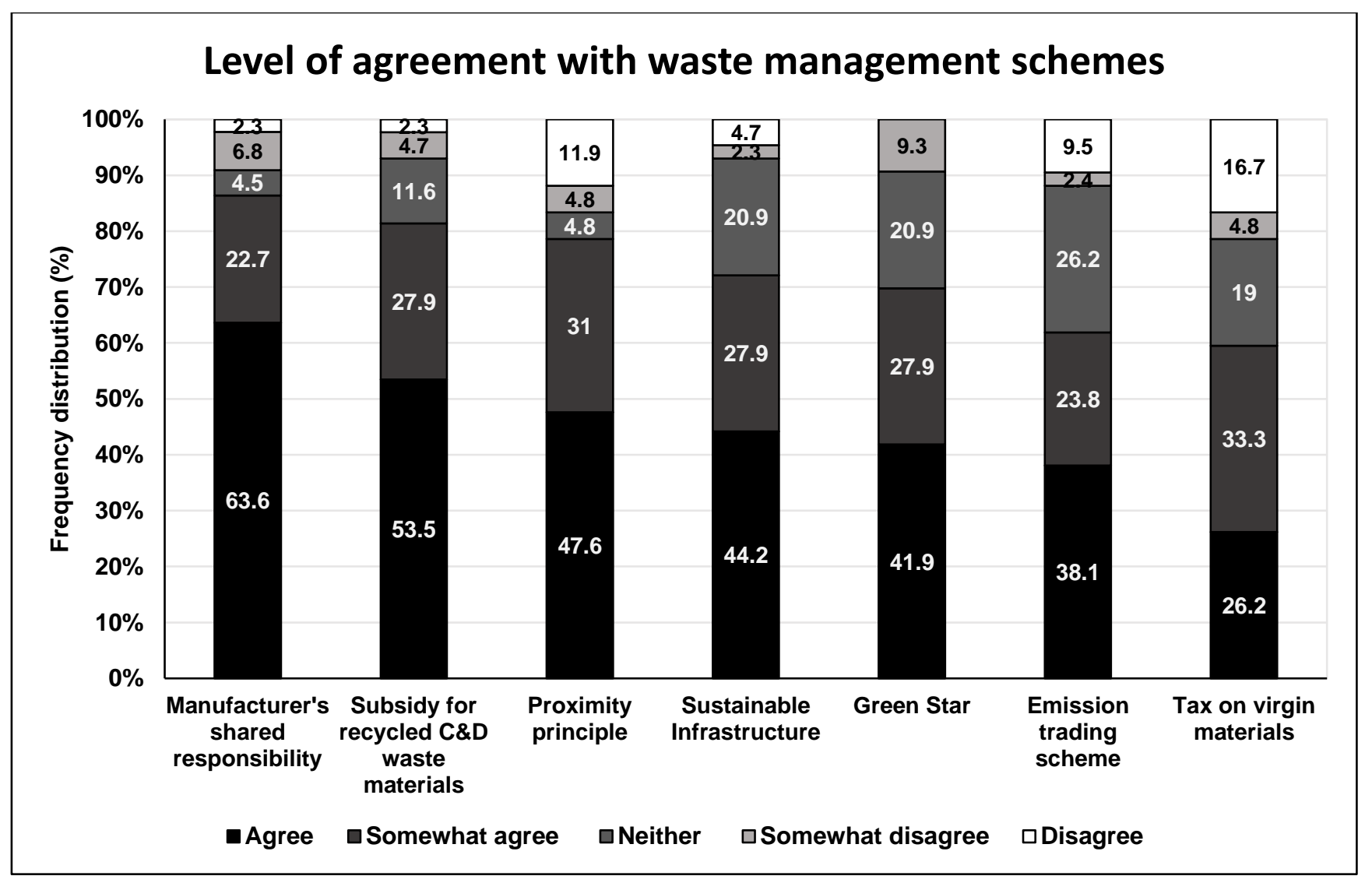

Figure 6. Participants agreement level with various (advisory/mandatory) schemes

\section{Discussion}

\subsection{Challenges ahead of C\&D waste management}

The three top challenges indicated by participants were "overregulation, recycled materials acceptance criteria set by government agencies and increased testing", "lack of local market" and "culture, education, and attitude", and "culture, poor education (attitude and behaviour) and acceptance". The two most referenced categories of challenges refer to the fact that, despite participants having an appetite for waste material recovery in the industry, it is difficult to first satisfy acceptance criteria and, more importantly, finding a sustainable market for selling these products. However, it seems that government organisations such as 
VicRoads [26] and WA MainRoads [27] - that are responsible for creating acceptance (specifications) standards for recycled materials - do not provide required support for using recycled materials in infrastructure projects, where a large quantity of materials could be integrated into road, bridge, tunnel and railway transport projects. Some examples of qualitative responses included "WA requires much higher product testing of composition than other states", "in WA we have overwritten specifications that we can't match in manufacture" and "DWER imposed test regimes and MRWA practices actively discourage users acceptable contaminant levels in recovered CED materials". The responses also suggested that the current increased product testing level unfavourably adds to recycled product manufacturing expenses, making them less competitive compared to virgin extracted materials. Some examples are: "too much testing of CED material vs virgin product-added expense", "increased testing \& QA costs not economical when compared to virgin materials" and "DWER testing requirements for products. Correspondingly, improvements in this area (providing a national guideline that determines the accepted level of contamination for reusing C\&D waste) was rated as the highest priority (Figure 5). One respondent said "Standards - there should be a consistent set of national standards for recycled CED products and end-uses to provide confidence to the market".

Lack of market is another issue that various organisations and associations have attempted to address, among other priorities. In the current National Waste Policy [9] under Strategy 14 (market development and research), all Australian governments and businesses were encouraged to support creating and maintaining markets for recycled materials, both domestically and internationally. Market development hinges on several factors that need to be collectively taken into account. Shooshtarian, et al. [28] identified seven main factors that included regulatory support, design and implementation of extended producer responsibility (EPR) scheme, the establishment of the effective and integrated supply chain, sustainable procurement scheme, investments in technology and infrastructure, research and development and properly designed landfill levy imposition. On the same note, Caldera, et al. [29] stated that market-based policy instruments could be developed through taxes, subsidies and other incentives to encourage waste diversion from landfills, recycling and create a second life for waste material. To market the recycled material as a substitute for natural raw materials, it is essential to increase awareness and carry out promotional 
activities. A continuous supply of clean waste streams is then necessary to produce highquality recycled content that satisfies the given technical specifications and is economically competitive.

Education, together with enforcement and encouragement, has a decisive role in the establishment of an effective waste management system. In the National Waste Policy [9] strategy 3 (knowledge sharing, education and behaviour change), it is advised that coordinated knowledge sharing and education initiatives should be implemented to address the needs of governments, businesses and individuals, and to encourage the redesign, reuse, repair, resource recovery, recycling and reprocessing of products. Most Australian jurisdictions have formed teams dedicated to educating industry people as well as the wider community [30]. Furthermore, jurisdictional waste strategies have introduced initiatives to fund education programs aiming to reduce waste and illegal dumping [16]. However, there is an ongoing debate about the individual role of education in promoting sustainable behaviour and attitudes in this context. For instance, Mckenzie-Mohr [31] has highlighted that, when it comes to sustainable behaviour, education alone has little or no effect and concluded that improving knowledge and changing attitudes may not have an impact on behaviour. On the other hand, Chapman, et al. [32] observed that experiential learning results in new habits and actively experiencing things is the most effective way to learn about environmental initiatives. A study in Australia [14] found that decisions on waste management practices in the construction industry are based on their financial return. The authors highlighted the importance of imposing legislation to enhance waste management practices until such practices become culturally embedded in organisations across the supply chain. Therefore, it can be inferred that education and the cultural shift need to be in keeping with encouragement and enforcement.

\subsection{Role of the federal government}

The top three categories of the federal government impact on C\&D waste management in participants' opinions were "building confidence in C\&D recycled materials in the market", "providing national leadership and coordination of C\&D waste efforts" and "developing 
effective legislation" (Figure 2). In our view, these three categories are interconnected and go hand in hand. The federal government, as the national leader [11], can be highly influential in building confidence in C\&D recycled materials, notably through introducing effective legislation. The federal government can work with state governments and other associations to develop regulations and policies that can support and encourage healthy and sustainable C\&D waste management activities. In the Australian National Waste Policy 2018 [9] one of the roles assumed by the federal government is to develop national standards for products and materials that are in accordance with the main issue of Australian waste management identified by participants.

\subsection{Regulations and policies}

As noted in the two previous sections, regulationsare the cornerstone of C\&D waste management and the area into which the federal government should interfere. The findings in this section showed that current regulations and policies are not encouraging further waste recovery (Figure 3) and the main areas of improvement are concerned with "illegal dumping and stockpiling activities", "definition of waste versus resource" and "extended producer responsibility" (Figure 4). The state developed regulations are not consistent in these areas, and perhaps the first step towards improvements is to harmonise the specifications of these categories. Any inconsistencies in these areas can significantly impact national efforts for the development of a market for recycled $C \& D$ waste in a negative way. In terms of non-legislative policies, in participants' opinions "manufacturer's shared responsibility of waste generation", "subsidy for C\&D waste recycled materials" and "proximity principle" are of high priority (Figure 6). The selection of these three response categories echoes participants' concern about the economics of waste recycling activities. All of these three categories have a similar objective: to reduce the cost of waste recycling in one way. According to the shared responsibility policy, construction material manufacturers are urged to contribute to expenses of waste management actively. Offering a subsidy on recycled materials can make them more economically competitive, and the proximity 
principle will boost activity in local recycling facilities by providing sustainable feedstock and local market development.

\section{Conclusion}

This study aimed to identify the main challenges and opportunities for enhancement of C\&D waste management in Australian using the key stakeholders' views as captured through an online survey. The study could provide information within three important dimensions of waste management, namely, the main C\&D waste challenges, the position of the federal government and regulation and policy development. The study's key highlights include the immediate need for improvement in the current legislation landscape, as it currently does not provide the support required for further waste recovery activities. The federal government has to become bold in the coordination of efforts leading to sustainable $C \& D$ waste management across the country, and develop policies and strategies that facilitate market development. The results also showed that, to operate an effective C\&D waste management system, encouragemetn, enforcement and education should be considered equally. The findings provide a sound basis for future researchers to address the challenges identified. The study also raises awareness of policymakers and industry practitioners of the genuine needs and requirements of effective C\&D waste management.

\section{Acknowledgements}

The authors would like to acknowledge the support of the Australian Sustainable Built Environment National Research Centre, Project 1.65. However, the views expressed in this article are those of the authors and do not necessarily represent the views of SBEnrc. 


\section{References:}

1. Australian Bureau of Statistics. "Building Activity", edited by Australian Bureau of Statistics, 2017.

2. Park, Jungha, and Richard Tucker. "Overcoming Barriers to the Reuse of Construction Waste Material in Australia: A Review of the Literature." International Journal of Construction Management 17, no. 3 (2017): 228-37.

3. Pickin, J, P Randell, J Trinh, and B Grant. "National Waste Report 2018." Canberra, Australia: Australian Department of the Environment and Energy, 2018.

4. Wu, Huanyu, Jian Zuo, Hongping Yuan, George Zillante, and Jiayuan Wang. "Cross-Regional Mobility of Construction and Demolition Waste in Australia: An Exploratory Study." Resources, Conservation and Recycling 156 (2020): 104710.

5. Forghani, R, W Sher, S Kanjanabootra, and Y Totoev. "Consequence of Waste Levy Revocation: Case Study Queensland, Australia." In 23 ${ }^{\text {rd }}$ Annual Pacific Rim Real Estate Society Conference on The Built Environment and Health, Infrastructure and System Resilience Planning. Sydney, Australia Sydney University of Technology, 2017.

6. Chileshe, Nicholas, Raufdeen Rameezdeen, M Reza Hosseini, Steffen Lehmann, and Chika Udeaja. "Analysis of Reverse Logistics Implementation Practices by South Australian Construction Organisations." International Journal of Operations $\mathcal{E}$ Production Management (2016).

7. Laviano, Hannah, Jordan Barlow, Monica Ton, and Noor Dawood. "Waste and Recycling Industry in Australia: A Submission to the Senate Inquiry ", 2017.

8. Shooshtarian, S, T Maqsood, M Khalfan, P Wong, and R Yang. "Managing Construction and Demolition (C\&D) Waste in Australia." In CIB World Building Congress 2019 'Constructing Smart Cities'. Hong Kong, China: Faculty of Construction and Environment, The Hong Kong Polytechniques University, 2019.

9. National Waste Policy. "Less Waste. More Resources", edited by Australian Government, 2018.

10. Hyder. "Waste Definitions and Classifications: Report on Issues, Opportunities and Information Gaps." Hyder Consulting Pty Ltd, 2012.

11. Environment and Communications References Committee. "Never Waste a Crisis: The Waste and Recycling Industry in Australia." Canberra, Australia Parliament of Australia 2018.

12. Edge Environment. "Construction and Demolition Waste Guide - Recycling and Reuse across the Supply Chain." Canberra, Australia: The Department of Energy and Environment 2012.

13. Udawatta, Nilupa, Jian Zuo, Keri Chiveralls, Hongping Yuan, Zillante George, and Abbas Elmualim. "Major Factors Impeding the Implementation of Waste Management in Australian Construction Projects." Journal of Green Building 13, no. 3 (2018): 101-21.

14. Udawatta, Nilupa, Jian Zuo, Keri Chiveralls, and George Zillante. "Attitudinal and Behavioural Approaches to Improving Waste Management on Construction Projects in Australia: Benefits and Limitations." International Journal of Construction Management 15, no. 2 (2015): 137-47. 
15. Shooshtarian, S., T. Maqsood, M. Khalfan, J.R. Yang, and Wong S.P. P. "Landfill Levy Imposition on Construction and Demolition Waste: Australian Stakeholders' Perceptions " Sustainability (2020).

16. Shooshtarian, S, T Maqsood, SP.P Wong, and M Khalfan. "Review of Waste Strategy Documents in Australia: Analysis of Strategies for Construction and Demolition Waste." International Journal of Environment and Waste Management (2020).

17. Hanisch, Carola. "Is Extended Producer Responsibility Effective?" Environmental science \& technology 34, no. 7 (2000): 170-75.

18. OECD. Extended Producer Responsibility: Updated Guidance for Efficient Waste Management, Organisation for Economic Cooperation and Development. Paris: OECD Publishing, 2016.

19. Lu, Weisheng, and Hongping Yuan. "A Framework for Understanding Waste Management Studies in Construction." Waste management 31, no. 6 (2011): 1252-60.

20. $\quad$ UK's HM Revenue \& Customs. "Aggregate Levy Manual." 2016.

21. Hyder. "Construction and Demolition Waste Status Report: Management of Construction and Demolition Waste in Australia". Australia Department of Energy and Environment (Department of Sustainability, Environment, Water, Population and Communities), 2011.

22. Shooshtarian, S, T Maqsood, SP. Wong Peter, Khalfan Malik, and Yang Rebecca. "Green Construction and Construction and Demolition Waste Management in Australia." In 43rd AUBEA Conference: Built to Thrive: Creating Buildings and Cities That Support Individual Well-Being and Community Prosperity. Noosa, Australia: CQ University, 2019.

23. Damptey, E.F. Optimising the Use of Recycled C\&D Waste Material in Civil Construction Projects. PhD, Swinburne University of Technology, Melbourne, Australia, 2011.

24. Pew Center on Global Climate Change. "Cap and Trade." In Climate Change 101: Understanding and Responding to Global Climate Change Pew Center on Global Climate Change., 2011.

25. Qualtrics, LLC. "Qualtrics [Software]." Utah, USA: Qualtrics (2014).

26. VicRoads. "Contract (Standard) Documents." Melbourne, Australia VicRoads, 2020.

27. WA MainRoads. "Specifications: 500 Series-Pavements". Perth, Australia 2020.

28. Shooshtarian, S, T Maqsood, S.P. P Wong, M Khalfan, and R.J Yang. "Development of a Domestic Market for Construction and Demolition Waste in Australia." In 43rd AUBEA Conference: Built to Thrive: Creating Buildings and Cities That Support Individual Well-Being and Community Prosperity. Noosa, Australia: CQ University, 2019.

29. Caldera, S, T Ryley, and N Zatyko. "Developing a Marketplace for Construction and Demolition Waste." Paper presented at the 1st Asia Pacific SDEWES Conference: Engineering a Sustainable Circular Economy: Materials, Energy and Infrastructure Integration for Smart Cities and Industry, Gold Coast, Australia, 6-9 April 2020.

30. National Waste Report. "Australian National Waste Report 2016." Department of the Environment and Energy, 2016. 
31. Mckenzie-Mohr, D. "Preface." In Motivating Change: Sustainable Design and Behaviour in the Built Environment, edited by Lehmann S Crocker R, xxiv-xxxi. Abingdon: Routledge, 2013.

32. Chapman, Janine, Natalie Skinner, and Sharni Searle. "Working Towards Sustainability: Exploring the Workplace as a Site for Pro-Environmental Behavioural Change." In Motivating Change: Sustainable Design and Behaviour in the Built Environment, 88-102: Routledge, 2013.

33. Forghani, Reza, Willy Sher, Sittimont Kanjanabootra, and Yuri Totoev. "The Attitudes of Demolition Contractors to Reusing Building Components: A Study in New South Wales, Australia." European Journal of Sustainable Development 7, no. 3 (2018): 364-64.

34. Udawatta, Nilupa, Jian Zuo, Keri Chiveralls, and George Zillante. "Attitudinal and Behavioural Approaches to Improving Waste Management on Construction Projects in Australia: Benefits and Limitations." International Journal of Construction Management 15, no. 2 (2015): 137-47.

35. Tam, Vivian, Khoa Le, Jiayuan Wang, and I Illankoon. "Practitioners Recycling Attitude and Behaviour in the Australian Construction Industry." Sustainability 10, no. 4 (2018): 1212.

36. Teo, Melissa MM, Martin Loosemore, M Masosszeky, and K Karim. "Operatives Attitudes Towards Waste on a Construction Project." Paper presented at the Annual Conference-ARCOM 2000. 